\title{
Agroforestry Practices in Midhills of Nepal from Gender Perspective
}

\author{
Deepa Paudel1* $^{*}$, Krishna Raj Tiwari¹, Nani Raut ${ }^{2}$, Bishal K. Sitaula ${ }^{3}$, Prabin Poudel1 ${ }^{1}$ \\ ${ }^{1}$ Institute of Forestry, Tribhuvan University, Pokhara, Nepal \\ ${ }^{2}$ Department of Environmental Science and Engineering, School of Science, Kathmandu University, Dhulikhel, Nepal \\ ${ }^{3}$ Department of International Environment and Development Studies, Norwegian University of Life Sciences, Ås, Norway \\ Email: ^skt.deepa@gmail.com, krishna.iof@gmail.com,rautnani7@gmail.com,bishal.sitaula@nmbu.no, \\ me.prashma@gmail.com
}

How to cite this paper: Paudel, D., Tiwari, K. R., Raut, N., Sitaula, B. K., \& Poudel, P. (2019). Agroforestry Practices in Midhills of Nepal from Gender Perspective. Open Journal of Forestry, 9, 323-340.

https://doi.org/10.4236/ojf.2019.94018

Received: July 31, 2019

Accepted: October 8, 2019

Published: October 11, 2019

Copyright (C) 2019 by author(s) and Scientific Research Publishing Inc. This work is licensed under the Creative Commons Attribution International License (CC BY 4.0).

http://creativecommons.org/licenses/by/4.0/

\begin{abstract}
Agroforestry practice is becoming compassionate option for rural communities to fulfil basic needs and generate income for households' wellbeing. Gender consideration seems worthful to obtain optimum benefits from agroforestry practices in the scarcity of male labour in the locality. This paper has attempted to analyse tendency of gendered participation in agroforestry practice and their existence in gaining benefits. We selected three mid-hills districts of Nepal where people are adopting both traditional (fulfilling subsistence needs) and improved (commercial purpose along with fulfilling subsistence needs) practices. We organized focused group discussions $(n=9)$, randomly sampled $(\mathrm{n}=420)$ households for interview from each practice $(\mathrm{n}=$ 210) to analyse gendered wise participation in farm establishment, management intervention, capacity building and access to information, known as major agroforestry promoting activities. Key informant interview $(\mathrm{n}=18)$, focused group discussions $(n=9)$, randomly sampled $(n=420)$ households for interview from each practice $(n=210)$ was organized to analyse gendered wise participation in farm establishment, management intervention, capacity building and access to information, known as major agroforestry promoting activities. Women participation seemed to be higher in establishment activities than male in traditional practices whereas males were front in applying chemical fertilizer and pesticides and irrigation in improved practices. While changing in practices from traditional to improved, male participation during land tillage found to be significant. Male domination was observed in making decisions regarding species selection in traditional practices whereas women domination was observed in improved practices. Men's involvement in species selection and plantation was found significant with changing in practices from traditional to improved. Men were ahead in capacity building and skill
\end{abstract}


development activities in traditional practices but women were more active in improved practices. Women participation in training and meetings was found significant between traditional and improved practice. Neighbours were major source of information in traditional whereas extension workers/programmes were major bases to learn new ideas and techniques to improved practitioner. Technologies and learning environment are less friendly to women so they have limited access to adopt new technologies. Exploration of gendered friendly programme and technologies is recommended to promote improved practices and maximize benefits from agroforestry.

\section{Keywords}

Traditional, Improved, Gender, Benefits, Technology

\section{Introduction}

The agroforestry practices, combination of agricultural and forestry practices, is a system of natural resources management that integrates trees on farms and in the agricultural landscape (Paudel et al., 2017; Brandt et al., 2013; FAO/IFAD/The World Bank, 2009) and generates ecological and economic benefits to rural poor (Verheij, 2003; Debbarma et al., 2015; Abebe \& Mulu, 2017). Agriculture and forestry, major sectors for livelihood (Upadhyay, 2005; CBS, 2011; Asian Development Bank, 2010), contribute 35\% of gross domestic product in Nepal (MOF, 2012; Bhattarai et al., 2015). About 2 billion people ensure food security for those people living in poverty from smallholder farms with agroforestry practice in the world (FAO, 2017). Agroforestry practice has ensured better welfare to community in overall where women involvement is essential part for sustaining agricultural production and management interventions (Kiptot et al., 2014; Debbarma et al., 2015; Bhattarai et al., 2015; Upadhyay, 2005). Because of diverse necessities, priorities and concerns, traditionally, male and female roles and responsibilities vary across regions (Sunderland et al., 2014; Bonnard \& Scherr, 1994; Aryal \& Zoebisch, 2004) and they often follow gender division of labour (Bechtel, 2010; Mai et al., 2011).

Gender is societal relationship between women and men that refer the action how these groups deal, perceive and experience as per norms and traditions (Yorburg, 1973; Sanders, 1977; Eagly, 1987; FAO, 1997). Gender is key consideration in natural resource management either in agriculture or forestry where women role seemed to be worthful in utilizing traditional knowledge for the better management of natural and forest resources (IFAD, 2012) but their roles vary with type of the agroforestry practices and preference. Even in the absence of men, women are contributing widely in any event of agroforestry practices (Asse \& Lassoie, 2011; Mendez et al., 2001; Rahman et al., 2012; Brandt et al., 2013; Debbarma et al., 2015) so they should be considered as integral part of agroforestry system (Debbarma et al., 2015). Women's contributions beyond the 
household chores have been made visible since the 1970s but women and gender concerns are still academically unexplored or inadequately highlighted (Asher \& Varley, 2018; Fortmann \& Rocheleau, 1985). Women play influential role to obtain optimal benefits (Kiptot \& Franzel, 2011; Debbarma et al., 2015) but their efforts have not been accredited significantly despite several attempts to decrease gendered discrimination (Eccles, 1987; Asher \& Varley, 2018). Conservation efforts that exclude women in those communities fail to identify and deal with gender differences, will contribute to increase poverty, inequality, and resource degradation (Bechtel, 2010). Women perform intensively in agroforestry; from beginning of establishment to final harvest and marketing (Upadhyay, 2005) but their roles in resources management are often ignored while documenting contribution (Both ENDS, 2010; Kiptot \& Franzel, 2012) and they are limited within on subsistence issue (Rocheleau \& Edmunds, 1997; Chikoko, 2002; Doss, 2001; Mehra \& Rojas, 2008). Men's out migration for income generation has significantly increased women's workload in agriculture and forest based activities (Bhattarai et al., 2015) thus agriculture and forestry sector is being feminised in Nepal. Women contribution in agriculture sectors is nearly similar to men in Nepal (MoADFS, 2017) and increasing continuously (Bhattarai et al., 2015) but they are owing less than $20 \%$ agricultural land (UNDP, 2017). Despite women's noteworthy involvement in agroforestry activities (MoADFS, 2017), their participation in decision-making remained low due to traditional discriminating deals (Neupane, 2002) and their overall contribution is also often ignored. This situation has been reducing women participation in agroforestry and affecting to obtain better results (Bechtel, 2010; Kiptot \& Franzel, 2012). Therefore, this study was conducted in order to appraise women contribution for the promotion of agroforestry and compare based on gender perspective. The finding of our study will contribute to enhancing women ownership toward agroforestry practices and their access to opportunities that ultimately contribute agricultural productivity and societal benefits.

\section{Study Area}

Three sites were selected from the mid-hills of Nepal (See Figure 1). Chhang, Nirmal Pokhari and Karen danda were taken from Tanahun, Kaski and Syanjya districts respectively for the study where agroforestry practices are being adopted for more than 10 years. Landuse of midhills is mixed with agriculture and tree crops so there was difficulty to identify the different agroforestry practices. Criteria were defined with the help of farmers and forest users and through focused group discussion. Basically, two cases; what kind of agriculture practice and purposes of adopting these practices?, were considered in the study. Some people have been practicing agroforestry from ancient time for household needs and some adopting agroforestry for the commercial purpose. Six points (Table 1) were followed to differentiate agroforestry practice. Existing agroforestry practices were broadly categorized as traditional (home garden, fallow land with seasonal 


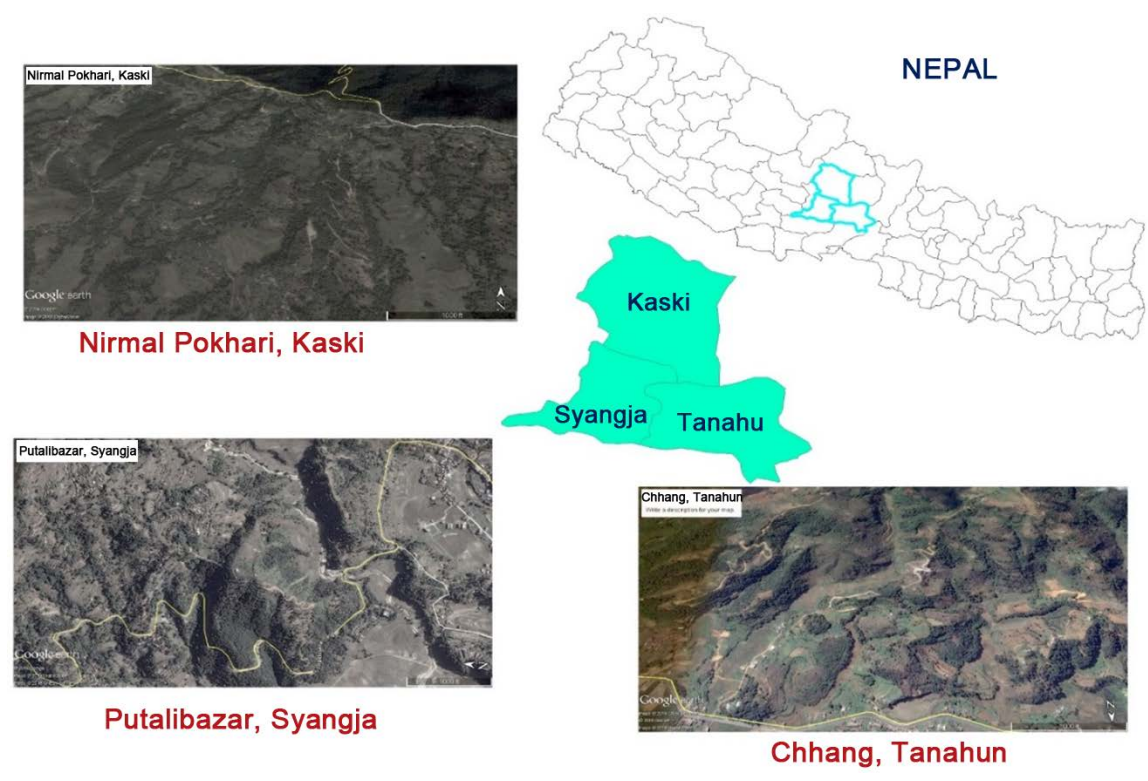

Figure 1. Map of study area.

Table 1. Criteria to differentiate traditional and improved agroforestry practice.

\begin{tabular}{cccc}
\hline SN & Criteria & Traditional & Improved \\
\hline $\mathbf{1}$ & Purpose & Subsistence & Commercial \\
$\mathbf{2}$ & Average land holding size (Ropani) & 1.8 & 5.7 \\
$\mathbf{3}$ & Average No. of & & 45 \\
& trees/perennial plant $\mathrm{HH}^{-1}$ & 12 & \\
$\mathbf{4}$ & Cropping pattern & $\begin{array}{c}\text { Tree on boarder + } \\
\text { vegetable/agriculture crop }\end{array}$ & $\begin{array}{c}\text { Tree }+ \text { cash crop + } \\
\text { vegetable/grass }\end{array}$ \\
$\mathbf{5}$ & Practice period & Time immemorial & A decade (recent) \\
$\mathbf{6}$ & Strata composition & Two storeys & Multi storey \\
\hline
\end{tabular}

grazing, tree on farmland) and improved (commercial fruit orchards, coffee plantation and fodder trees with agriculture crops) practices. With the aim of generating optimal benefits, people have initiated improved form of agro-forestry practices and introduced cash crop in the assistance of different supporting agencies and local co-operative has been facilitating for product marketing.

\section{Data Collection}

Data were collected through key informant interviews, individual household representative interviews, focus group discussions and field observation. Eighteen key informants were interviewed to select specific site and village having both traditional and improved agroforestry practices. Two field enumerators were trained and mobilized to conduct individual household representative interviews as questionnaire survey in a confidential environment. We prepared structured questionnaire and pre-tested it before entertaining interview with in- 
dividual household level. Then, individual household representatives were interviewed to collect information about adopted agroforestry practices, socio-economic characteristics, gender involvement in establishment, management and capacity development of agroforestry practices, role of local institutions and available source of information for the promotion of agroforestry practice. 420 people were interviewed in total where 140 from each district. Out of this 140,70 were traditional practitioner and 70 were improved practitioners. In our study sites; there are $200-225$ people who are adopting improved practices. We followed as suggested by (Israel, 1992) to fix the sample size $(\mathrm{n}=70) \pm 10 \%$ precision levels where confidence level is $95 \%$ and $P=0.5$. For the consistency, we selected 70 people in case of traditional practitioner in each site. Firstly, people who are adopting traditional and improved practices in the locality were listed and out of them 70 people were randomly selected from each practices of each sites. Therefore, a total of 210 number of individual household representatives from improved agroforestry practices and in same number from traditional practices were entertained for the data collection. This means, 70 numbers of individual household representatives from each district for each practice were selected. Furthermore, collected information was crosschecked through nine focus group discussions having 6 - 9 people in each discussion. Based on the questionnaire survey, a checklist was also prepared prior to facilitate group discussion for crosschecking information taken through individual household representative interview.

\section{Results}

Activities adopted in agroforestry practice were broadly divided into three categories; farm establishment, management intervention and capacity building with skill development of farmers in order to obtain optimum benefits from applied practices. In addition, "access to information" was also considered as another major factor for promoting agroforestry practice. Then, tendency of men and women participation in these three categories while undertaking traditional and improved agroforestry practices was appraised.

\subsection{Farm Establishment in Agroforestry}

Within the traditional and improved practices, five activities; ploughing, tillage, farmyard manure (FYM) application, chemical fertilizer application, pesticide application and irrigation were assessed as major activities and involvement of male and female in organizing these activities was also appraised. Ploughing is that activity which is totally performed by male. Local social and cultural norms do not allow women in ploughing; however somewhere, incidence can be found as an exception in current context. In traditional agroforestry practices, females' involvement was observed higher in all activities with compare to male whereas male involvement was found to be higher in chemical fertilizer application, pesticide application and irrigation in improved practices (Table 2). Female involved 
Table 2. Participation in establishment activities of agroforestry practice.

\begin{tabular}{lccccccc}
\hline & & \multicolumn{7}{c}{ Agroforestry system (\% involvement) } & \multirow{2}{*}{ SN } & \multirow{2}{*}{ Activity } & \multicolumn{3}{c}{ Traditional $(\mathrm{n}=210)$} & Improved $(\mathrm{n}=210)$ & \multirow{2}{*}{$\chi^{2}$} & \multirow{2}{*}{ Significance } \\
\cline { 3 - 6 } & & Male & Female & Male & Female & & \\
\hline $\mathbf{1}$ & Tillage & 18.6 & 81.4 & 34.8 & 65.2 & $14.075^{\mathrm{a}}$ & $0.000^{*}$ \\
$\mathbf{2}$ & FYM use & 12.9 & 87.1 & 13.3 & 86.7 & $0.021^{\mathrm{a}}$ & 0.885 \\
$\mathbf{3}$ & Chemical fertilizer use & 47.1 & 52.9 & 57.1 & 42.9 & $4.208^{\mathrm{a}}$ & 0.040 \\
$\mathbf{4}$ & Pesticide application & 46.7 & 53.3 & 56.2 & 43.8 & $3.813^{\mathrm{a}}$ & 0.051 \\
$\mathbf{5}$ & Irrigation & 45.7 & 54.3 & 53.3 & 46.7 & $2.438^{\mathrm{a}}$ & 0.118 \\
\hline
\end{tabular}

${ }^{*}$ Significant at $5 \%$.

maximum in tillage (81.4\%) and FYM application (87.1\%). FYM application has been considered as women task in village and women also involved more in physically less loaded (compare to ploughing) tillage activity. While changing in practices from traditional to improved, we observed change in men and women participation in every activity, but change in male participation in tillage was found significant (5\%). Male prefers those activities from which more income in terms of cash can be generated so their involvement is seemed to be high in improved practices with compare to traditional however women involvement is higher in overall. This indicates that women are more responsible in establishing activities with compare to male either in traditional and improved practices.

\subsection{Management Intervention in Agroforestry}

Species selection, plantation, fodder and product harvesting are important management operations for promoting agroforestry and generating optimal benefits. We recorded women involvement higher in establishment phase so we expected that their involvement in management and utilization phase would be also higher than male. But male domination was found in deciding species selection in traditional practices whereas women in improved practices (Table 3). The reason behind this might be women were found more interested to change their current practices to have more benefits. While changing in practices from traditional to improved, we observed change men and women participation in every management activity, but the involvement of male in species selection and plantation was found significantly different (5\%). Female involvement in all management operations of both practices was found to be higher than the male except in selecting species in traditional practices. This means women involvement in management operation and utilization of products is high as we observed in establishment.

\subsection{Capacity Building and Skill Development Activity in Agroforestry}

The knowledge on related subject matter influences decision making while adopting 
Table 3. Participation in management activities in agroforestry.

\begin{tabular}{cccccccc}
\hline & & \multicolumn{3}{c}{ Agroforestry system (\% involvement) } & & \\
\cline { 3 - 6 } SN & Activity & \multicolumn{2}{c}{ Traditional $(\mathrm{n}=210)$} & Improved $(\mathrm{n}=210)$ & \multirow{2}{*}{$\chi^{2}$} & Significance \\
\cline { 3 - 6 } & & Male & Female & Male & Female & & \\
\hline $\mathbf{1}$ & Species selection & 51.9 & 48.1 & 41.4 & 58.6 & $4.630^{\mathrm{a}}$ & $0.031^{*}$ \\
$\mathbf{2}$ & Plantation & 36.2 & 63.8 & 45.7 & 54.3 & $3.938^{\mathrm{a}}$ & $0.047^{*}$ \\
$\mathbf{3}$ & Fodder collection & 15.7 & 84.3 & 21.9 & 78.1 & $2.635^{\mathrm{a}}$ & 0.105 \\
$\mathbf{4}$ & Product harvesting & 39.5 & 60.5 & 36.7 & 63.3 & $0.363^{\mathrm{a}}$ & 0.547 \\
\hline * Significant at 5\% level. & & & & & &
\end{tabular}

Table 4. Participation in capacity building activities of agroforestry practices.

\begin{tabular}{cccccccc}
\hline & & \multicolumn{9}{c}{ Agroforestry system (\% involvement) } & & \\
\cline { 3 - 5 } SN & \multirow{2}{*}{ Activity } & \multicolumn{2}{c}{ Traditional $(\mathrm{n}=210)$} & \multicolumn{2}{c}{ Improved $(\mathrm{n}=210)$} & \multirow{2}{*}{$\chi^{2}$} & Significance \\
\cline { 3 - 5 } & & Male & Female & Male & Female & & \\
\hline $\mathbf{1}$ & Training & $57.1 \%$ & $42.9 \%$ & $41.0 \%$ & $59.0 \%$ & $11.014^{\mathrm{a}}$ & $0.001^{*}$ \\
$\mathbf{2}$ & Meeting attend & $55.2 \%$ & $44.8 \%$ & $41.9 \%$ & $58.1 \%$ & $7.473^{\mathrm{a}}$ & $0.006^{*}$ \\
$\mathbf{3}$ & Marketing & $49.0 \%$ & $51.0 \%$ & $45.2 \%$ & $54.8 \%$ & $0.612^{\mathrm{a}}$ & 0.434 \\
\hline
\end{tabular}

* = Significant at $5 \%$ level.

new technologies with the aim of obtaining measurable benefits. Exposure to new technique, access in decision-making and knowledge of product marketing are also the most important factors for promoting agroforestry practice. Sex wise beneficiaries in getting opportunities related with agroforestry promotion in our study sites were appraised. Male participation was observed high in training (57.1\%) and meeting (55.2\%) in traditional practices area but, reversely, women participation was found to be more in both training (59\%) and meeting (58.1\%) in improved practice (Table 4). Women participation in training and meetings were found to be significant (5\%) between traditional and improved practice. In case of marketing of goods, women participation was seemed to be high in traditional practice $(51 \%)$ and male in improved practiced areas. Women role in selling agroforestry products was high with compare to male in both practices. Frequency of male and female participation was different in both practices in case of marketing products (sale) but no any significant.

\subsection{Access to Agroforestry Promotion Information}

There are different sources of information for the daily activities, but here we focused only in those sources of information that are convenient to study area and majority of people rely on such as neighbour, radio/television (audio/video), newspaper (print media), extension worker/programme etc. In traditional practice maximum number of people get information from their neighbour and followed by radio/television, newspaper and extension worker/programme while in improved practices, extension workers/programmes are major sources for learning 
new technique and management of products. However, neighbours, newspaper, radio/television are also sources of information for the improved agroforestry practitioner (See Figure 2).

\section{Discussion}

Rural households are still obligated in continuing subsistence farming practices to feed their family and fulfil basic needs (Kiptot \& Franzel, 2012). Moreover, some households have been shifting their farming practices to modern form for obtaining multiple benefits and high income. We observed two school of thoughts; continuing traditional or adopting modified agroforestry practice, in the locality. The traditional agroforestry practices have been gradually changing from self-subsistence to commercial production in our study areas. Social and cultural consideration; men as household head and women as supportive actor of men, have restricted women's access to land, market and trading, decision-making process (Gebrehiwot et al., 2018). However, women are known as ancient domesticators of important plant species (Kumar \& Nair, 2004; Eyzaguirre \& Linares, 2004), have better understanding on household requirements (Daniggelis, 2003) and promoter of agroforestry practices at local level (Kumar \& Nair, 2004; Eyzaguirre \& Linares, 2004). Disparity in workloads between male and female household members in agricultural occupation (Gebrehiwot et al., 2018; Maharjan et al., 2012) is widening gender gap and now feminizing agricultural occupation more deepen in Nepal due to male out migration (Maharjan et al., 2012), that also seen in our study. Women's contribution is being identified (Gebrehiwot et al., 2018) and gender equality in environmental sustainability emerged as major agenda of sustainable development (Meinzen-Dick et al., 2014a, 2014b) but in the name of gender, disparity on role and responsibilities, rights to access and control over land and farm products are still existing (Gebrehiwot et al., 2018). Despite equally responsible in fulfilling household need, male and female involvement in agroforestry activities differs due to time availability and nature of work (Halbrendt et al., 2014). Besides household chore routines, women involve agroforestry practice, but their contribution is always invisible (Gebrehiwot et al., 2018), if visible often undermined.

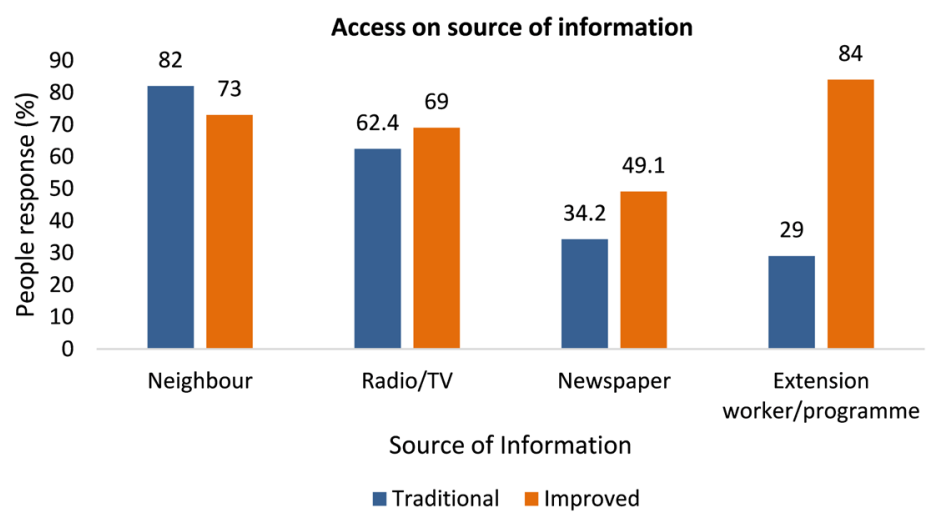

Figure 2. Farmer assess to source of information. 
Male out migration and absence of male youth in village have enhanced women responsibilities, that has impacted not only on women participation in societal task but also in households task and agricultural occupation (Devkota \& Pyakuryal, 2017; Maharjan et al., 2012). Larger remittances minimize women's physical work burden but added more responsibilities in household and community whereas low remittance kept women under pressure of physical work and time management burden (Maharjan et al., 2012). Women and women's groups targeted extension activities facilitated by women put positive role to enhance women participation (Kiptot \& Franzel, 2012).

\subsection{Farm Establishment in Agroforestry}

As we observed in our study, Maharjan et al. (2012); Halbrendt et al. (2014); Mulyoutami et al. (2016); Both ENDS (2010) also found tradition of disparity in work division between men and women. Due to cultural belief, ploughing is specifically categorized as male chore, however, nowadays female also involves in ploughing and tillage activities in few cases in some region of the world (Halbrendt et al., 2014; Maharjan et al., 2012) which are similar to our findings. Mystical belief "if women plough land, misfortune and natural calamities may occur in households and locality" in the society has kept female away from ploughing (Maharjan et al., 2012). Besides the ploughing, both male and female involve in most of the activities of agroforestry but the extent of their involvement differs with respect to labour and time availability, knowledge, physical power etc. in many cases (Maharjan et al., 2012; Halbrendt et al., 2014) which is also in line with our studies. Physically tough, but not totally, activities (e.g. land preparation) are mostly considered as men work while dividing responsibilities $(\mathrm{Mu}-$ lyoutami et al., 2016). Land preparation, tree planting, harvesting and supervision are men's duties whereas women handle nursery activities; site and seed preparation, watering and general maintenance of the nursery in Uganda $(\mathrm{Mu}-$ kadasi \& Nabalegwa, 2007). Nursery, land maintenance (weeding, clearing, etc.), and growing and harvesting of coconuts, are generally carried out by men because these activities are heavy and physically challenging (Mulyoutami et al., 2016). Ploughing, irrigation, fertilization, pesticide application, and threshing are traditionally allotted tasks to males and activities; planting, hoeing, and thinning comes under female responsibility in Syanjya and Baitadi Nepal (Maharjan et al., 2012). Men manage ploughing and women conduct the majority of fertilizer application, weeding, and harvesting (Halbrendt et al., 2014) which also supports our findings. Men and female non significantly involve in improved fallow in Zambia (Phiri et al., 2004; Keil et al., 2005; Ajayi et al., 2001) in Kenya (Kiptot, 2007; Place et al., 2004; Kiptot, 2008; Franzel, 1999) in Malawi (Thangata \& Alavalapati, 2003) whereas significantly participate in Uganda (Buyinza \& Wambede, 2008) and in Kenya (Obonyo \& Franzel, 2004). Women used improved fallows and biomass transfer technologies more than men however they often used fertilizer in western Kenya (Place et al., 2004). 
High percentage of women participation in all non-traditional farming activities except ploughing verifies not only involvement in farming but also work division based on gender in farming (Maharjan et al., 2012) however their degree of participation varies with time and labour availability. Seed sowing and transplanting were mostly considered women's tasks in traditional farming practices, however the work was more evenly distributed between men and women in improved practices (Halbrendt et al., 2014). In traditional homegardens, women participate in production and processing of vegetables, fruits, dairy products, and food distribution whereas men involve in tilling, cultivation and wholesale trading of cash crops (Gebrehiwot et al., 2018). More than $80 \%$ women participate in all agriculture activities in another districts of Nepal but their involvement is found to minimum in pesticide and fertilizer application (Maharjan et al., 2012). We found women involvement high in both traditional and improved practices as (Halbrendt et al., 2014) found in both conventional and conservation practices of agroforestry, however there is no significant difference in women participation in major activities while changing practices from one to another. While shifting towards improved practices, more labour requires for ploughing, sowing, and harvesting and less for fertilizer application and weeding, this additional required labour is often fulfilled from women (Halbrendt et al., 2014). We also observed same experienced in our study. Male out-migration is creating more pressure on females to undertake extra agricultural activities (Maharjan, 2010) and provoking feminization in agricultural sector (Gartaula et al., 2010; Maharjan et al., 2012). In traditional farming practice, men conducted $46.9 \%$ of total labour and women $53.1 \%$, in case of improved practices, a similar trend was maintained, with men completing $46.0 \%$ of total labour and women $54.0 \%$, respectively (Halbrendt et al., 2014) which seem in line with our study.

\subsection{Management Intervention in Agroforestry}

We found that women are not being taken as major stake as per their contribution in decision making process of agroforestry practice in traditional practice. However, women participation in decision making seemed high, it might be due to male outmigration and less availability in village. Patriarchal tradition, household head dominance, exposure in related issues are the important factors in household and community level for decision-making so female get few chances to take part in decision making process (Halbrendt et al., 2014). Because of social understanding, men have right of decision making and they often decide almost all issue without consulting their family members (Gebrehiwot et al., 2018). Access to resources and ownership of assets such as; land, house, animals, and money encourage male for taking risk and responsibilities of decision making. Men are land owners in majorities of households so they are more responsible for deciding trees in Uganda (Gombya-Ssembajjwe \& Banana, 1998) which is matching with our findings. Both male and female participate in many agroforestry activities; species selection, plantation, fodder collection and product har- 
vesting, but degree their involvement differs because of some reasons such as labour availability, time availability, skill and nature of work (Debbarma et al., 2015; Maharjan et al., 2012; Halbrendt et al., 2014; Mulyoutami et al., 2016). Male outmigration has made women household head and they feel ownership towards assets and also involve decision making many cases (Maharjan et al., 2012) but they often expect husband words to confirm their decision. Such own habitual aspect is making women more weaken to keep their views strongly in decision making process. Women share their ideas in selecting species to be grown, but men solely decide species at time of plantation (Kiptot \& Franzel, 2012). However, women's decision-making role is greater in operational matters than in strategic affairs (Maharjan et al., 2012). The growing and harvesting of coconuts is also generally carried out by men because the work is quite heavy, expensive and physically challenging (Mulyoutami et al., 2016) we also have same experience in our study sites when physically tough activities have to be done. Halbrendt et al., 2014 have same findings as ours; male dominancy seems maximum in most of the activities; however, some decisions are made in common understanding whereas female do decision in the absence of male. Women often involve in collection and drying of fallen coconuts, whereas men carrying the dried flesh (Mulyoutami et al., 2016). Women are forward in identifying valuable plant species in Amazonia (Shanley \& Gaia, 2001) and in raising local fruit trees in Africa (Campbell, 1987), but their roles seem negligible in decision making and harvesting activities (Daniggelis, 2003). Women, domesticators of important plant species (Kumar \& Nair, 2004; Eyzaguirre \& Linares, 2004), have better understanding on household requirements than men (Daniggelis, 2003), but often keep themselves behind in case of decision making. As concluding remarks, women also participate in several management-based activities but they expect men's intervention in final decision in most of the activities even in the absence of male in households.

\subsection{Capacity Building and Skill Development in Agroforestry}

We observed that agroforestry practice either traditional or improved consists knowledge and skill intensive activities and needs more resources; time and materials and women are behind to have equal opportunities to take part in training, meeting, marketing of products and mobilizing generated funds. Women, well dweller of plant domestication (Kumar \& Nair, 2004; Eyzaguirre \& Linares, 2004) and household requirement manager (Daniggelis, 2003), but they are biased in opportunity distribution. Though agroforestry offers considerable benefits (Teklehaimanot, 2004; Fondoun \& Tiki-Manga, 2000; Ayuk et al. 1999; Kiptot \& Franzel, 2012), degree of women participation in benefits sharing seems gendered bias. Female also involve in marketing of agroforestry products (Mulyoutami et al., 2016) but male dominancy ethos excludes women in decision making and prejudices women in benefits and income sharing in many cases (Gebrehiwot et al., 2018). Men focused on wholesale and export market 
while women were restricted only for small scale trading business in local market in traditional agroforestry practice, whereas marketing of products was fully controlled under men in improved practices (Gebrehiwot et al., 2018). Women are confined to the lower end of the value chain (retailing) in marketing activities, which limits their control over and returns from the productive process (Kiptot \& Franzel, 2012). With the change in practices (growing cash crop), women are prohibited to enter farm with the reason of "women entering into farm negatively affect its production" that exclude them completely from its production and benefits (Gebrehiwot et al., 2018). Women participation is found to be less in enterprises having high commercial value and more in those enterprises having little or no commercial value (collection of indigenous fruits and vegetables) (Kiptot \& Franzel, 2012). Market is under the control of males in Europe, Asia and Africa where women support labour during selling products in Asia and Africa (Both ENDS, 2010). Women are not allowed to buy and sell livestock, if widowed women need to sell or buy, they have to ask male (neighbour or relative) to do it, whereas men can do entire action freely (Gebrehiwot et al., 2018). Women cannot perform well due to dearth of knowledge and resources (Kiptot \& Franzel, 2012) nevertheless they highly contribute in adopting agroforestry practices (Kumar \& Nair, 2004; Eyzaguirre \& Linares, 2004; Campbell, 1987; Shanley \& Gaia, 2001; Debbarma et al., 2015). Limited knowledge and male dominant local institution and program significantly reduce women ability in using rights, sharing their problems and placing ideas while needed (Gebrehiwot et al., 2018; Kiptot \& Franzel, 2012), however many extension activities are being organized to support women's rights against discriminatory traditional rules and disparity culture (Gebrehiwot et al., 2018). Encouraging for group work, training on improving productivity and marketing of products and increasing women's access to information are key components to enable women in agroforestry activities in fullest (Kiptot \& Franzel, 2012; Maharjan et al., 2012). Women contribution should be recognized in fullest and the components preferred by women in agroforestry must be introduced and practiced to get higher benefits in sustain basis (Debbarma et al. 2015). Women strengthening actions; training on marketing of products, empowering women's access to information and resources and introducing gender friendly technologies (Kiptot \& Franzel, 2011; Debbarma et al., 2015), are needed to bring out women from traditionally burdened role and responsibilities and ensure gender equity in all activities and confirming better benefit to them (Kiptot \& Franzel, 2012). Most of agroforestry technologies are unfriendly to women, therefore female farmers are less likely to adopt new technologies with compare to male (Adesina \& Chianu, 2002; Tiwari et al., 2009; Dhakal et al., 2015).

\subsection{Access to Agroforestry Promotion Information}

As in our study, though there are many options for gaining knowledge, women have limited access to agricultural extension in compare to men and extension 
services are also gendered bias in many countries of Africa (Gilbert et al., 2013; Katungi et al., 2008; Doss \& Morris, 2000; Kiptot \& Franzel, 2012). Women therefore are beyond to have new skill, knowledge and enhance their ability to share their problems and views. Many extension activities are being organized to support women's rights against discriminatory traditional rules and norms (Gebrehiwot et al., 2018) but women participation in extension program is found less because most of these activities are not women friendly such as not specific program for women, facilitators of extension programme are often male. Mounting women participation and their access to information through women specific training, interaction, meeting and extension activities assure women full representation in all activities (Kiptot \& Franzel, 2012; Maharjan et al., 2012). The adoption of improved technology assures more benefits where adoption of new technologies depends on farmers' interest, availability of extension services and medium of knowledge transfer (Kiptot \& Franzel, 2012; Katungi et al., 2008). Women focused strengthening actions; group work, training on marketing of products, strengthening women's access to information, technologies, decision making, are needed to bring out women from traditionally burdened role and responsibilities and ensure gender equity in all activities and confirming better benefit to women (Kiptot \& Franzel, 2012).

\section{Conclusion}

Two school of thoughts; continuing traditional or adopting modified agroforestry practice, are still existing in the locality but agroforestry practices have been gradually changing towards commercial production i.e. from traditional to improved practices. Disparity in workloads between men and women in agricultural occupation has been widening gender gap and now feminizing agricultural occupation more deepen due to male out migration and increase in women responsibilities. Considering women as supportive actor of men has restricted women's access in opportunities, decision-making, training, meetings and marketing of products. Women contribute higher in many activities either of traditional or of improved agroforestry practice, but they are still deprived to participate in capacity building and skill development activities as per their contribution due to unfriendly technologies and learning environment. Gendered friendly programme (women-focused and also facilitated by women) and technologies (physically feasible) are needed to explore for the promotion of improved practices to maximize benefits from agroforestry in current context.

\section{Acknowledgements}

We would like to thank NORHED SUNREM Himalaya Project for South Asia for providing financial support for this study. We were thankful to all the farmers involved in the questionnaire survey. Thanks are extended to people who assisted during field works, especially, Pawan Karki, Sistata Bagale, Sara Ranabhat, Ram Thapa, and Resham Karki. 


\section{Conflicts of Interest}

The authors declare that there are no conflicts of interest regarding the publication of this paper.

\section{References}

Abebe, T., \& Mulu, D. (2017). The Role of Women in the Management and Utilization of Home Garden: The Case of Dale District, in Southern Ethiopia. Asian Journal of Plant Science and Research, 7, 41-54.

Adesina, A. A., \& Chianu, J. (2002). Determinants of Farmers' Adoption and Adaptation of Alley Farming Technology in Nigeria. Agroforestry Systems, 55, 99-112. https://doi.org/10.1023/A:1020556132073

Ajayi, O. C., Ayuk, E. T., Massi, C., Phiri, D., \& Kwesiga, F. K. (2001). Typology and Characteristics of Farmers Planting Improved Fallows in Eastern Zambia (No. 2). Working Paper.

Aryal, S. S., \& Zoebisch, M. (2004). The Role of Women in Land Management and Conservation-A Case from the Middle-Hill Region of Nepal. In The 13th International Soil Conservation Organisation Conference. Brisbane, Australia.

Asher, K., \& Varley, G. (2018). Gender in the Jungle: A Critical Assessment of Women and Gender in Current (2014-2016) Forestry Research. International Forestry Review, 20, 149-159. https://doi.org/10.1505/146554818823767537

Asian Development Bank (2010). Overview of Gender Equality and Social Inclusion in Nepal. Asian Development Bank.

Asse, R., \& Lassoie, J. P. (2011). Household Decision-Making in Agroforestry Parklands of Sudano-Sahelian Mali. Agroforestry Systems, 82, 247-261. https://doi.org/10.1007/s10457-011-9395-2

Ayuk, E. T., Duguma, B., Franzel, S., Kengue, J., Mollet, M., Tiki-Manga, T., \& Zenkeng, P. (1999). Uses, Management and Economic Potential of Garcinia kola and Ricinodendron heudeloth in the Humid Lowlands of Cameroon. Economic Botany, 53, 292-301. https://doi.org/10.1007/BF02866641

Bechtel, J. (2010). Gender, Poverty and the Conservation of Biodiversity: A Review of Issues and Opportunities. MacArthur Foundation Conservation White Paper Series.

Bhattarai, B., Beilin, R., \& Ford, R. (2015). Gender, Agrobiodiversity, and Climate Change: A Study of Adaptation Practices in the Nepal Himalayas. World Development, 70, 122-132. https://doi.org/10.1016/j.worlddev.2015.01.003

Bonnard, P., \& Scherr, S. (1994). Within Gender Differences in Tree Management: Is Gender Distinction a Reliable Concept? Agroforestry Systems, 25, 71-93. https://doi.org/10.1007/BF00705669

Both ENDS (2010). Gender Mainstreaming in Natural Resources Management: Why and How? Amsterdam, The Netherlands: Nieuwe Keizersgracht.

Brandt, R., Mathez-Stiefel, S. L., Lachmuth, S., Hensen, I., \& Rist, S. (2013). Knowledge and Valuation of Andean Agroforestry Species: The Role of Sex, Age, and Migration among Members of a Rural Community in Bolivia. Journal of Ethnobiology and Ethnomedicine, 9, 83. https://doi.org/10.1186/1746-4269-9-83

Buyinza, M., \& Wambede, N. (2008). Extension for Agroforestry Technology Adoption: Mixed Intercropping of Crotolaria (Crotolaria grahamiana) and Maize (Zea mays L.) in Kabale District, Uganda. Environmental Research Journal, 2, 131-137.

Campbell, B. M. (1987). The Use of Wild Fruits in Zimbabwe. Economic Botany, 41, 
375-385. https://doi.org/10.1007/BF02859054

CBS (2011). Statistical Year Book of Nepal. Central Bureau of Statistics.

Chikoko, M. G. (2002). A Comparative Analysis of Household Owned Woodlots and Fuelwood Sufficiency between Female and Male-Headed Households: A Pilot Study in Rural Malawi, Africa. Corvallis, OR: Oregon State University.

Daniggelis, E. (2003). Women and 'Wild' Foods: Nutrition and Household Security among Rai and Sherpa Forager-Farmers in Eastern Nepal. In P. L. Howard (Ed.), Women \& Plants: Relations in Biodiversity Management and Conservation. New York, London: Zed Books and St. Martin's Press.

Debbarma, J., Taran, M., \& Deb, S. (2015). Contribution of Women in Agroforestry Practices of West Tripura, North-East India. Octa Journal of Environmental Research, 3, 343-351.

Devkota, D., \& Pyakuryal, K. N. (2017). Changed Gender Roles and Rural Agricultural System. Journal of Agriculture and Forestry University, 1, 35-47.

Dhakal, A., Cockfield, G., \& Maraseni, T. N. (2015). Deriving an Index of Adoption Rate and Assessing Factors Affecting Adoption of an Agroforestry-Based Farming System in Dhanusha District, Nepal. Agroforestry Systems, 89, 645-661. https://doi.org/10.1007/s10457-015-9802-1

Doss, C. R. (2001). Designing Agricultural Technology for African Women Farmers: Lessons from 25 Years of Experience. World Development, 29, 2075-2092. https://doi.org/10.1016/S0305-750X(01)00088-2

Doss, C. R., \& Morris, M. L. (2000). How Does Gender Affect the Adoption of Agricultural Innovations? The Case of Improved Maize Technology in Ghana. Agricultural economics, 25, 27-39. https://doi.org/10.1111/j.1574-0862.2001.tb00233.x

Eagly, A. H. (1987). Sex Differences in Social Behaviour: A Social Role Interpretation. Hillsdale, NS: Erlbaum.

Eccles, J. S. (1987). Gender Roles and Women's Achievement-Related Decisions. Psychology of Women Quarterly, 11, 135-172. https://doi.org/10.1111/j.1471-6402.1987.tb00781.x

Eyzaguirre, P. B., \& Linares, O. F. (2004). Home Gardens and Agrobiodiversity. Washington DC: Smithsonian Books.

FAO (1997). Food and Agriculture Organization. Gender Equity in Agriculture and Rural Development: A Quick Guide to Gender Mainstreaming in FAO's New Strategic Framework.

FAO (2017). Strengthening Sector Policies for Better Food Security and Nutrition Results. Food and Agriculture Organization.

FAO/IFAD/The World Bank (2009). Gender in Agriculture Sourcebook. The World Bank, Food and Agriculture Organization, and International Fund for Agricultural Development.

Fondoun, J. M., \& Manga, T. T. (2000). Farmers Indigenous Practices for Conserving Garcinia kola and Gnetum africanum in Southern Cameroon. Agroforestry Systems, 48, 289-302. https://doi.org/10.1023/A:1006393709637

Fortmann, L., \& Rocheleau, D. (1985). Women and Agroforestry: Four Myths and Three Case Studies. Agroforestry Systems, 2, 253-272. https://doi.org/10.1007/BF00147037

Franzel, S. (1999). Socioeconomic Factors Affecting the Adoption Potential of Improved Tree Fallows in Africa. Agroforestry Systems, 47, 305-321.

https://doi.org/10.1023/A:1006292119954 
Gartaula, H. N., Niehof, A., \& Visser, L. (2010). Feminisation of Agriculture as an Effect of Male out-Migration: Unexpected Outcomes from Jhapa District, Eastern Nepal. International Journal of Interdisciplinary Social Sciences, 5, 565-578. https://doi.org/10.18848/1833-1882/CGP/v05i02/51588

Gebrehiwot, M., Elbakidze, M., \& Lidestav, G. (2018). Gender Relations in Changing Agroforestry Homegardens in Rural Ethiopia. Journal of Rural Studies, 61, 197-205. https://doi.org/10.1016/j.jrurstud.2018.05.009

Gilbert, R. A., Sakala, W. D., \& Benson, T. D. (2013). Gender Analysis of a Nationwide Cropping System Trial Survey in Malawi.

Gombya-Ssembajjwe, W., \& Banana, A. Y. (1998). Property Rights and the Sustainability of Forests in Uganda. In Crossing Boundaries. Vancouver, British Columbia, Canada: The Seventh Annual Conference of the International Association for the Study of Common Property.

Halbrendt, J., Kimura, A. H., Gray, S. A., Radovich, T., Reed, B., \& Tamang, B. B. (2014). Implications of Conservation Agriculture for Men's and Women's Workloads among Marginalized Farmers in the Central Middle Hills of Nepal. Mountain Research and Development, 34, 214-223. https://doi.org/10.1659/MRD-JOURNAL-D-13-00083.1

IFAD (2012). Gender Equality and Women's Empowerment. Rome, Italy: IFAD.

Israel, G. D. (1992). Determining Sample Size 1.

Katungi, E., Edmeades, S., \& Smale, M. (2008). Gender, Social Capital and Information Exchange in rural Uganda. Journal of International Development: The Journal of the Development Studies Association, 20, 35-52. https://doi.org/10.1002/jid.1426

Keil, A., Zeller, M., \& Franzel, S. (2005). Improved Tree Fallows in Smallholder Maize Production in Zambia: Do Initial Testers Adopt the Technology? Agroforestry Systems, 64, 225-236. https://doi.org/10.1007/s10457-004-2410-0

Kiptot, E. (2007). Seeing beyond Fertiliser Trees: A Case Study of a Community Based Participatory Approach to Agroforestry Research and Development in Western Kenya.

Kiptot, E. (2008). Adoption Dynamics of Tithonia Diversifolia for Soil Fertility Management in Pilot Villages of Western Kenya. Experimental Agriculture, 44, 473-484.

https://doi.org/10.1017/S0014479708006704

Kiptot, E., \& Franzel, S. (2012). Gender and Agroforestry in Africa: A Review of Women's Participation. Agroforestry Systems, 84, 35-58. https://doi.org/10.1007/s10457-011-9419-y

Kiptot, E., \& Franzel, S. C. (2011). Gender and Agroforestry in Africa: Are Women Participating? Nairobi: World Agroforestry Centre. https://doi.org/10.5716/OP16988

Kiptot, E., Franzel, S., \& Degrande, A. (2014). Gender, Agroforestry and Food Security in Africa. Current Opinion in Environmental Sustainability, 6, 104-109. https://doi.org/10.1016/j.cosust.2013.10.019

Kumar, B. M., \& Nair, P. K. R. (2004). The Enigma of Tropical Home Gardens. Agroforestry Systems, 61, 135-152. https://doi.org/10.1023/B:AGFO.0000028995.13227.ca

Maharjan, A. (2010). Labour out Migration and Its Impact on Farm Families in the Mid Hills of Nepal.

Maharjan, A., Bauer, S., \& Knerr, B. (2012). Do Rural Women Who Stay behind Benefit from Male out-Migration? A Case Study in the Hills of Nepal. Gender, Technology and Development, 16, 95-123. https://doi.org/10.1177/097185241101600105

Mai, Y. H., Mwangi, E., \& Wan, M. (2011). Gender Analysis in Forestry Research: Looking Back and Thinking Ahead. International Forestry Review, 13, 245-258. https://doi.org/10.1505/146554811797406589 
Mehra, R., \& Rojas, M. H. (2008). Women, Food Security and Agriculture in a Global Marketplace. Washington DC: International Center for Research on Women (ICRW).

Meinzen-Dick, R., Johnson, N., Quisumbing, A., Njuki, J., Behrman, J., Rubin, D., Peterman, A., \& Waithanji, E., (2014a). The Gender Asset Gap and Its Implications for Agricultural and Rural Development. In A. Quisumbing, R. Meinzen-Dick, T. Raney, A. Croppenstedt, J. Behrman, \& A. Peterman (Eds.), Gender in Agriculture and Food Security: Closing the Knowledge Gap. Springer and FAO: Dordrecht, The Netherlands. https://doi.org/10.1007/978-94-017-8616-4_5

Meinzen-Dick, R., Kovarik, C., \& Quisumbing, A. R. (2014b). Gender and Sustainability. Annual Review of Environment and Resources, 39, 29-55. https://doi.org/10.1146/annurev-environ-101813-013240

Mendez, V. E., Lok, R., \& Somarriba, E. (2001). Interdisciplinary Analysis of Homegardens in Nicaragua: Micro-Zonation, Plant Use and Socioeconomic Importance. Agroforestry Systems, 51, 85-96. https://doi.org/10.1023/A:1010622430223

MoADFS (2017). Selected Indicators of Gender and Social Inclusion in Agriculture Sector and Related Agricultural Programs. Kathmandu, Nepal: Government of Nepal Ministry of Agricultural Development Food Security, Agribusiness Promotion and Environment Division Gender Equity and Social Inclusion Section Singh Durbar.

MOF (2012). Economic Survey 2011/12. Kathmandu: Ministry of Finance, Government of Nepal.

Mukadasi, B., \& Nabalegwa, M. (2007). Gender Mainstreaming and Community Participation in Plant Resource Conservation in Buzaya County, Kamuli District, Uganda. African Journal of Ecology, 45, 7-12. https://doi.org/10.1111/j.1365-2028.2007.00730.x

Mulyoutami, E., Awalina, D., Martini, E., Khususiyah, N., Isnurdiansyah, Janudianto, Wau D., \& Suyanto. (2016). Agroforestry and Forestry in Sulawesi Series: Women's Participation in Agroforestry: More Benefit or Burden? A Gendered Analysis of Gorontalo Province. Working Paper 226. Bogor, Indonesia: World Agroforestry Centre (ICRAF) Southeast Asia Regional Program. https://doi.org/10.5716/WP16036.PDF

Neupane, R. (2002). Gender and Agroforestry in the Hills of Nepal. Gender, Technology and Development, 6, 427-438. https://doi.org/10.1080/09718524.2002.11910058

Obonyo, E., \& Franzel, S. (2004). Biomass Transfer Technology Experiences in Western Kenya. In Proceedings of the 2nd Kenya Forestry Scientific Conference on Recent Advances in Forestry Research and Technology Development (pp. 350-358.). Muguga: Kenya Forestry Research Institute.

Paudel, D., Tiwari, K. R., Bajracharya, R. M., Raut, N., \& Sitaula, B. K. (2017). Agroforestry System: An Opportunity for Carbon Sequestration and Climate Change Adaptation in the Mid-Hills of Nepal. Octa Journal of Environmental Research, 5.

Phiri, D., Franzel, S., Mafongoya, P., Jere, I., Katanga, R., \& Phiri, S. (2004). Who Is Using the New Technology? The Association of Wealth Status and Gender with the Planting of Improved Tree Fallows in Eastern Province, Zambia. Agricultural Systems, 79, 131-144. https://doi.org/10.1016/S0308-521X(03)00055-6

Place, F., Franzel, S., Noordin, Q., \& Jama, B. (2004). Improved Fallows in Kenya: History, Farmer Practice, and Impacts. Washington DC: Intl Food Policy Res Inst.

Rahman, S. A., Imam, M. H., Snelder, D. J., \& Sunderland, T. (2012). Agroforestry for Livelihood Security in Agrarian Landscapes of the Padma Floodplain in Bangladesh. Small-Scale Forestry, 11, 529-538. https://doi.org/10.1007/s11842-012-9198-y

Rocheleau, D., \& Edmunds, D. (1997). Women, Men and Trees: Gender, Power and Property in Forest and Agrarian Landscapes. World Development, 25, 1351-1371. https://doi.org/10.1016/S0305-750X(97)00036-3 
Sanders, I. T. (1977). Rural Society. Upper Saddle River, NJ: Prentice-Hall Foundations of Modern Sociology Series.

Shanley, S., \& Gaia, G. R. (2001). Equitable Ecology: Collaborative Learning for Local Benefit in Amazonia. Agriculture Systems, 73, 83-97. https://doi.org/10.1016/S0308-521X(01)00101-9

Sunderland, T., Achdiawan, R., Angelsen, A., Babigumira, R., Ickowitz, A., Paumgarten, F., \& Shively, G. (2014). Challenging Perceptions about Men, Women, and Forest Product Use: A Global Comparative Study. World Development, 64, S56-S66. https://doi.org/10.1016/j.worlddev.2014.03.003

Teklehaimanot, Z. (2004). Exploiting the Potential of Indigenous Agroforestry Trees: Parkia biglobosa and Vitellaria paradoxa in Sub-Saharan Africa. In P. K. R. Nair, M. R. Rao, \& L. E. Buck (Eds.), New Vistas in Agroforestry (pp. 207-220). Dordrecht: Springer. https://doi.org/10.1007/978-94-017-2424-1_15

Thangata, P. H., \& Alavalapati, J. R. R. (2003). Agroforestry Adoption in Southern Malawi: The Case of Mixed Intercropping of Gliricidia sepium and Maize. Agricultural Systems, 78, 57-71. https://doi.org/10.1016/S0308-521X(03)00032-5

Tiwari, T. P., Virk, D. S., \& Sinclair, F. L. (2009). Rapid Gains in Yield and Adoption of New Maize Varieties for Complex Hillside Environments through Farmer Participation: I. Improving Options through Participatory Varietal Selection (PVS). Field Crops Research, 111, 137-143. https://doi.org/10.1016/j.fcr.2008.11.008

UNDP (2017). Gender and Social Inclusion. Report. Nepal: United National Development Programme.

Upadhyay, B. (2005). Gender Aspects of Smallholder Irrigation Technology: Insights from Nepal. Journal of Applied Irrigation Science, 39, 315-327.

Verheij, E. (2003). Agroforestry (3rd ed.). Wageningen, The Netherlands: Agromisa Foundation.

Yorburg, B. (1973). The Changing Family. Columbia University Press. 